\title{
GENETIC PARAMETERS AND LINE SELECTION OF Cucurbita pepo BASED ON SELECTION INDICES
}

\section{PARÂMETROS GENÉTICOS E SELEÇÃO DE LINHAGENS DE Cucurbita pepo COM BASE EM ÍNDICES DE SELEÇÃO}

\author{
Igor Forigo BELOTI ${ }^{1 *}$; Gabriel Mascarenhas MACIEL ${ }^{2}$; Fernando Cezar JULIATTI $^{1}$; \\ Rafael Resende FINZI ${ }^{2}$; Daniel Bonifácio Oliveira CARDOSO ${ }^{1}$ \\ 1. Institute of Agricultural Sciences, Federal University of Uberlândia, Uberlândia, MG, Brazil; *agroifb@gmail.com; \\ 2. Institute of Agricultural Sciences, Federal University of Uberlândia, Monte Carmelo, MG, Brazil.
}

\begin{abstract}
In the improvement of pumpkins, the selection based on one or a few characters of interest tends to be less efficient, leading to a superior product only compared to the few characters selected. To maximize the simultaneous selection of multiple characteristics of interest, selection indexes are used to obtain a numerical value resulting from the combination of the characters on which the simultaneous selection is to be practiced. The objective of this study was to determine genetic parameters and the most appropriate selection indexes in strains of Summer squash (C. pepo). Statistical analyzes were performed based on 65 genotypes belonging to the vegetable germplasm bank of the Federal University of Uberlândia. The variables analyzed were: leaf area index, precocity, SPAD index, productivity. plant ${ }^{-1}$, number of fruits. Plant $^{-1}$, leaf temperature, NDVI index and NDRE index. The indexes were used: Smith (1936) and Hazel (1943), the sum of "Ranks" by Mulamba and Mock (1978), and Willians (1962). The selection methodologies selected ten individuals (15\% of the genotypes). The values found for $\mathrm{h}^{2}(\%)$ ranged from $36.92 \%$ (SPAD) to $59.65 \%$ (cycle). The values obtained in the $\mathrm{CVg} / \mathrm{CVe}$ quotient were below 1, varying from 0.18 for leaf temperature to 0.70 for the cycle, with the other variables close to 0.5 . The $\mathrm{CVg}$ genetic variation coefficient (\%) was also low, ranging from $1.84 \%$ for leaf temperature to $30.94 \%$ for productivity. The greatest gains obtained with direct and indirect selection were for the characters productivity $(35.92 \%)$, NDRE $(33.04 \%)$, number of fruits $(28.93 \%)$ and leaf area index (22.72\%). The Mulamba and Mock (1978) index showed the highest total selection gain value, providing a balanced distribution of selection gains, choosing the genotypes: $8,31,34,38,42,64,65,66,67$ and 68 .
\end{abstract}

KEYWORDS: Breeding. Selection gains. Summer squash.

\section{INTRODUCTION}

Summer squash (C. pepo L.) is a vegetable of great socioeconomic importance, especially for family farming in several countries. It belongs to the family Cucurbitaceae, with wide genetic variability, composed of more than 80 genera and 800 species of plants (FORMISANO et al., 2012).

In the pumpkin selection process, progenies are considered to have agronomic characteristics, mainly: precocity of the cycle, growth habit, productivity, resistance to pests and diseases, aspects of fruits such as color, firmness, shape in addition to the levels of carotenoids (BEZERRA NETO et al., 2006; BLANK et al., 2013; FERREIRA et al., 2016; SILVA, 2016; BORGES et al., 2019).

A plant breeding program depends on the existence of genetic variability, because through hybridizations it is possible to obtain individuals that gather favorable alleles of characteristics of interest (MATSUO; CRUZ; SEDYAMA, 2020).

The selection based on one or a few characters proves to be inadequate, leading to a superior final genotype only in relation to the few characters selected. It is a complex process, since the characters of agronomic importance are quantitative in nature, generally correlated with each other and, in most cases, of low heritability (NOGUEIRA et al., 2012; LEITE et al., 2016).

A device used to select several characters simultaneously, little known in cucurbits, is through selection indexes. The selection index technique allows an optimal linear combination of several characters, on which it is desired to practice the simultaneously selection (MATSUO; CRUZ; SEDYAMA, 2020). Different indices refer to the alternative of selection and gains, identifying quickly and efficiently the progenies that may be more suitable for the purposes of the breeder 
(VASCONCELOS et al., 2010; ROSADO et al., 2012; REZENDE et al., 2014).

Despite the potential of the selection index technique in different cultures, there is no knowledge on the genetic improvement of Cucurbita spp. The main methods used for selection indexes in breeding programs are: classic index proposed by Smith (1936) and Hazel (1943), Willians base index (1962) and the index based on the sum of Mulamba and Mock ranks. and they have different characteristics depending on the needs of the breeder (REZENDE et al., 2014).

The objective of the work was to determine genetic parameters and the best selection indexes in strains of Summer squash, for simultaneous selection of characters of economic interest.

\section{MATERIAL AND METHODS}

The experiment was carried out at the Experimental Vegetable Station (18 $42^{\prime} 43.19$ 'S and $47^{\circ} 29^{\prime} 55.8^{\prime \prime} \mathrm{W}, 873 \mathrm{~m}$ altitude), at the Seed Analysis and Genetic Resources Laboratory (LAGEN) and at the Remote Sensing Laboratory (LASER) of the Federal University of Uberlândia-UFU, Monte Carmelo campus.

The seven parental genotypes were obtained from collections performed in local free markets, and named as: "UFU-A", "UFU-B", "UFU-C", "UFU-D", "UFU-E", "UFU-F" and "UFU-G". From 2013, five successive self-fertilization were performed after hybridization between the accesses. The method of genetic improvement used was genealogical. Sixty-five $C$. pepo genotypes were obtained in the fifth generation (Table 1), through prior selection based on desirable fruit characteristics such as shape and color, number of male and female flowers, leaf temperature and SPAD index.

Table 1. C. pepo genotypes obtained after five self-fertilization and evaluated in the field experiment.

\begin{tabular}{|c|c|c|c|}
\hline Number & Genotype & Number & Genotype \\
\hline 3 & UFU $1 \# 1$ & 38 & UFU 77\#1 \\
\hline 4 & UFU 2\#1 & 39 & UFU 78\#1 \\
\hline 5 & UFU 3\#1 & 40 & UFU 79\#1 \\
\hline 7 & UFU 10\#1 & 41 & UFU 83\#1 \\
\hline 8 & UFU $11 \# 1$ & 42 & UFU 85\#1 \\
\hline 9 & UFU $12 \# 1$ & 43 & UFU 87\#1 \\
\hline 10 & UFU16\#1 & 44 & UFU 88\#1 \\
\hline 11 & UFU $17 \# 1$ & 45 & UFU 89\#1 \\
\hline 12 & UFU 19\#3 & 46 & UFU 90\#1 \\
\hline 13 & UFU $20 \# 2$ & 47 & UFU 93\#1 \\
\hline 14 & UFU 24\#1 & 48 & UFU 94\#1 \\
\hline 15 & UFU $28 \# 1$ & 49 & UFU 95\#1 \\
\hline 16 & UFU 29\#1 & 50 & UFU 96\#2 \\
\hline 17 & UFU 30\#1 & 51 & UFU $97 \# 2$ \\
\hline 18 & UFU 32\#1 & 52 & UFU 99\#1 \\
\hline 19 & UFU 33\#2 & 53 & UFU $102 \# 1$ \\
\hline 20 & UFU 36\#2 & 54 & UFU $104 \# 1$ \\
\hline 21 & UFU 41\#2 & 55 & UFU $105 \# 1$ \\
\hline 22 & UFU 42\#1 & 56 & UFU $110 \# 1$ \\
\hline 23 & UFU 43\#1 & 57 & UFU $111 \# 1$ \\
\hline 25 & UFU 46\#1 & 58 & UFU $118 \# 1$ \\
\hline 26 & UFU 47\#2 & 59 & UFU $121 \# 1$ \\
\hline 27 & UFU 54\#2 & 60 & UFU $124 \# 1$ \\
\hline
\end{tabular}




$\begin{array}{lccc}28 & \text { UFU 55\#1 } & 61 & \text { UFU 65\#1 } \\ 29 & \text { UFU 59\#2 } & 62 & \text { UFU 115\#1 } \\ 30 & \text { UFU 60\#3 } & 63 & \text { Tronco caserta } \\ 31 & \text { UFU 62\#1 } & 64 & \text { UFU-E } \\ 32 & \text { UFU 67\#2 } & 65 & \text { UFU-B } \\ 33 & \text { UFU 68\#1 } & 66 & \text { UFU-C } \\ 34 & \text { UFU 69\#1 } & 67 & \text { PX13067051 } \\ 35 & \text { UFU 71\#2 } & 68 & \text { UFU-G } \\ 36 & \text { UFU 72\#2 } & 69 & \text { UFU-A } \\ 37 & \text { UFU 76\#1 } & & \end{array}$

For the installation of the experiment, a soil sample was collected at a depth of 0 to $20 \mathrm{~cm}$, and chemical and physical analysis was performed, presenting the following results: clayey texture containing more than $50 \%$ of clay in its composition; $\mathrm{pH}$ in $\mathrm{CaCl}_{2}=4.9 ; \mathrm{OM}=3.9 \mathrm{dag} \mathrm{kg}^{-1}$; Pmeh $=79.1 \mathrm{mg} \mathrm{dm}^{-3} ; \mathrm{K}=0.29 \mathrm{cmol} \mathrm{dm}^{-3} ; \mathrm{Ca}=3.3$ cmoldm $^{-3} ; \mathrm{Mg}=1.3 \mathrm{cmol} \mathrm{dm}^{-3} ; \mathrm{H}+\mathrm{Al}=4.9 \mathrm{cmol}$ $\mathrm{dm}^{-3} ; \mathrm{SB}=4.90 \mathrm{cmol} \mathrm{dm}^{-3} ; \mathrm{T}=9.80 \mathrm{cmol} \mathrm{dm}^{-3} ;$ and $\mathrm{V} \%=50$. Given the soil analysis, the calculation of planting and mulching fertilizers was performed, as well as liming, as required by the summer squash crop (RIBEIRO et al., 1999).

Sowing was performed on 128-cell polystyrene trays with commercial coconut fiber substrate on October 6, 2018 in a greenhouse. The seedlings were transplanted 14 days after sowing to the field in a randomized block design (RBD). The 65 genotypes, in three blocks with four plants per plot, totaled 780 plants, spaced $0.7 \mathrm{~m}$ between plants and $1.2 \mathrm{~m}$ between lines, consisting of an area of $3.36 \mathrm{~m}^{2}$ per plot and a total area of $655.2 \mathrm{~m}^{2}$.

Weed management and pest and disease control were carried out by weekly monitoring, through chemical control. Irrigation was performed at a frequency of application according to the need of the plants by sprinkler irrigation system, avoiding the permanent wilting point.

According to the climate classification of Köppen and Geiger (1939), the local climate is Aw (tropical savanna). During the experiment period, the average temperature was $23.38{ }^{\circ} \mathrm{C}$, relative humidity of $81 \%$ and cumulative precipitation of $745.4 \mathrm{~mm}$ (Figure 1).
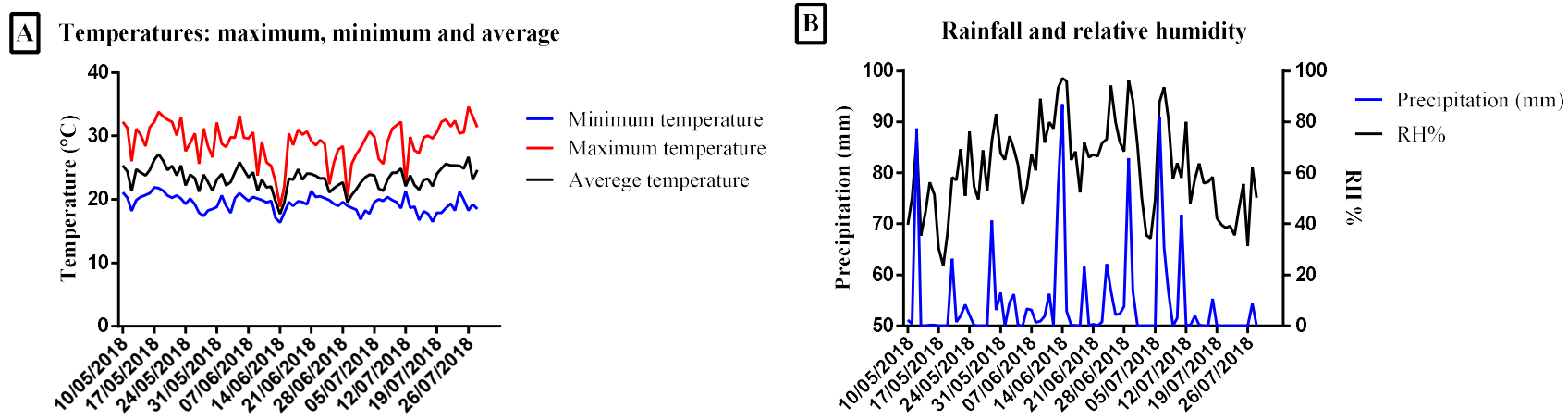

Figure 1. A) Minimum, maximum and average temperatures; B) Rainfall and relative humidity at the experiment site, from 10/05/2018 to 23/12/2018. Monte Carmelo, 2018.

The following characteristics were evaluated during the flowering / fruiting stage:

SPAD Index: performed in the flowering/fruiting phase with the aid of the Minolta SPAD-502 CFL1030 model chlorophyll meter. It has an accuracy of $\pm 1.0 \mathrm{SPAD}$ unit (for values between 0.0 and 50.0 at normal temperature/humidity). The center of the third expanded leaf, between 7:00 and 9:00 am, was sampled from four plants per plot, thus obtaining the average of the plot.

Leaf temperature $\left({ }^{\circ} \mathrm{C}\right)$ : performed from the positioning of an infrared thermometer (model 4000, 4GL, Everest Interscience, Tucson, AZ, 
USA), which has an accuracy of $\pm 0.3{ }^{\circ} \mathrm{C}$ at temperatures of -10 to $50{ }^{\circ} \mathrm{C}$. The upper leaves were sampled trying to point the sensor in the central position of the leaf surface in the third expanded leaf.

During the harvest period (when the fruits were fully expanded), the following were evaluated:

Yield $\left(\mathrm{kg} \mathrm{plant}^{-1}\right)$ : ratio between weight of harvested fruit by number of plants in the plot;

Number of fruits (fruits plant $^{-1}$ ): ratio between the total number of fruits and the number of plants in the plot;

Precocity: number of days to start the production cycle from transplantation to the field.

Leaf Area Index (LAI) $\left(\mathrm{m}^{2} \mathrm{~m}^{-2}\right):$ An unmanned aerial vehicle (Phantom4 Pro ${ }^{\odot}$ DJI) was used to capture the images at the field test points on November 23, 2018. Flight plans were planned and conducted using the DroneDeploy ${ }^{\mathcal{C}}$ application at a flight height of $50 \mathrm{~m}$ with a flight speed of $3 \mathrm{~ms}^{-2}$ overlaying 173 photos using a 20-megapixel resolution visible camera and a near 12-megapixel infrared camera (MAPIR). With the obtained images two orthophotos of the area of the experiment with the program $\mathrm{Pix} 4 \mathrm{~d}^{(}$were generated, one with the images taken with the camera visible with GSD (Ground Sample Distance) of $1 \mathrm{~cm}$ (resolution per pixel), another with the infrared images with GSD $5 \mathrm{~cm}$. The leaf area index was obtained by the ratio between leaf area $\left(\mathrm{m}^{2}\right)$ and plot area $\left(\mathrm{m}^{2}\right)$. The area was obtained using the infrared orthophoto and subsequently calculated using the Image $\mathrm{J}^{\odot}$ software by quantifying the pixels in the image $\left(1\right.$ pixel $\left.=1 \mathrm{~cm}^{2}\right)$.

At the end of the production cycle (beginning of leaf senescence), it was evaluated:

Normalized Difference Vegetation Index (NDVI) and Normalized Difference Red Edge Index (NDRE): A second flight was performed in the final phase of the experiment (12/22/2018), replacing the MAPIR chamber with a multi-spectral chamber (Micasense) Red Edge-M (Seattle, USA), coupled with a 3D kit developed by Sky Flight Robotics ${ }^{(}$ (Michigan, USA). The camera captures five images of the same resolution $(1280 \times 800)$ for five bands: $475 \mathrm{~nm}$ for Blue with $20 \mathrm{~nm}$ calculated bandwidth, maximum average bandwidth of $560 \mathrm{~nm}$, band 560 $\mathrm{nm}$ for Green with $20 \mathrm{~nm}$ bandwidth, band $668 \mathrm{~nm}$ for $10 \mathrm{~nm}$ bandwidth Red, band $840 \mathrm{~nm} 40 \mathrm{~nm}$ band Infrared (NIR) and band $717 \mathrm{~nm}$ for $10 \mathrm{~nm}$ band Red Edge. Radiometric calibration of the images was performed by capturing images from a reflectance panel calibrated at $1 \mathrm{~m}$ height immediately before and after the flight. The camera captured the images on a local digital card in 16- bit.tif format files. After capturing the images using UAV and the RedEdge camera, the images were processed using AgisoftPhotoScan software (www.agisoft.com) to obtain the mosaic. The NDVI and NDRE indexes of each plot were calculated using software that generates the results in the SOLVI cloud (solvi.nu).

The Normalized Difference Vegetation Index (NDVI, Equation (1)) was calculated from the difference and sum of the red band and NIR band reflectance values of the orthomosaic generated using the MicasenseRed Edge camera.

$N D V I=\frac{(\mathrm{NIR}-\mathrm{RED}]}{[\mathrm{NIR}+\mathrm{RED}]}$ (1)

The Border Red Normalized Difference Vegetation Index (NDRE, Equation (2)) was calculated from the difference and sum of the reflectance values of the near infrared band (NIR) and the red-edge band of the orthomosaic generated using the Micasense Red Edge camera.

NDRE $=\frac{(\text { NIR-RedEdge) }}{(\text { NIR+RedEdge })}(2)$

An NDVI threshold between 0.45 and 0.96 was used to capture green leaf reflectance and to exclude ground background reflectance. For NDRE the threshold was from 0.13 to 0.33 .

In order to assess the existence of genetic variability for quantitative traits, analyzes of variance were performed according to the model below. The genetic parameters and phenotypic, genotypic and residual correlations were obtained by the following estimators:

$$
\begin{aligned}
& \mathrm{h}^{2}=\frac{\sigma \mathrm{P}}{\frac{\mathrm{QMT}}{r}} \\
& \sigma \mathrm{P}=\frac{Q M T-Q M R}{r}
\end{aligned}
$$

On what:

$\mathrm{h}^{2}$ : genotypic determination coefficient; $\sigma \mathrm{P}$ : genetic quadratic component; QMT: average square of genotypes; QMR: average square of the residue; r: number of repetitions.

The parameters "Coefficient of genetic variation (CVg)" and "Coefficient of experimental variation (CVe)" indicate, respectively, the magnitude of the variations caused by deviations from the average due to genetic effects and those due to genetic effects and environmental effects. They are calculated as follows: 
Coefficient of genetic variation $(\mathrm{CVg})$ :

$C V_{g} \%=\frac{\sigma \mathrm{P}^{0.5}}{M} \times 100$

$\sigma \mathrm{P}=\frac{Q M T-Q M R}{r}$

On what:

$\mathrm{M}=$ experimental average

QMT: average square of genotypes;

QMR: average square of the residue;

r: number of repetitions.

Experimental coefficient of variation $(\mathrm{CVe})$ :

$C V_{e}=\frac{\sigma \mathrm{E}}{M} \times 100$

On what:

$\sigma \mathrm{E}=$ standard deviation of the experimental residue, equal to $\mathrm{QME}^{0.5}$

$\mathrm{M}=$ experimental average;

The selection gain was obtained through the product of the heritability value by the selection differential value, presenting the results in percentage values.

Selection gain $(\mathrm{SG} \%)$ :

$\left.S G(\%)=\left(X_{s i}-X_{o i}\right) h^{2} i=D S_{i} h^{2} X 100\right)$

On what:

$\mathrm{Xsi}=$ average of the strains selected for character $\mathrm{i}$;

Xoi $=$ original average of the population;

DS $\mathrm{i}=$ selection differential practiced in the population;

$h^{2} \mathrm{i}=$ heritability of character $\mathrm{i}$.

The estimates of selection gains were obtained through the methodologies using different indices: classic index proposed by Smith (1936) and Hazel (1943), Mulamba and Mock's rank index (1978) and base index of Willians (1962).

The classic index, proposed by Smith (1936) and Hazel (1943), consists of a linear combination of several characters of economic importance. The weighting coefficients are estimated in order to maximize the correlation between the index and the genotypic aggregate. This is established by another linear combination, involving genetic values, which are weighted by their respective economic values. The Willians base index (1962) proposes the establishment of indexes through the linear combination of the average phenotypic values of the characters, which are weighted directly by their respective economic weights (TEIXEIRA, 2017).

The Mulamba and Mock (1978) ranks sum index classifies the genotypes in relation to each character, in order favorable to improvement. This index has the advantage of eliminating the need to establish economic weights and estimating variances and covariance (REZENDE et al., 2014).

The classic index proposed by Smith (1936) and Hazel (1943) was estimated by the selection index (I) and the genotypic aggregate $(\mathrm{H})$ described as follows:

$$
\begin{aligned}
& I=b_{1} y_{1}+b_{2} y_{2}+\cdots+b_{n} y_{n}=\sum_{i=1}^{n} b i y i=y^{\prime} b \\
& H=a_{1} g_{1}+a_{2} g_{2}+\cdots+a_{n} g_{n}=\sum_{i=1}^{n} a i g i=g^{\prime} a
\end{aligned}
$$

On what:

n: number of characters evaluated;

$\mathrm{b}$ : vector of dimension $1 \times \mathrm{n}$ of the weighting coefficients of the selection index to be estimated;

$\mathrm{y}$ : dimension matrix $\mathrm{n} \times \mathrm{p}$ (plants) of phenotypic values of the characters;

a: it is the vector of dimension $1 \mathrm{x} \mathrm{n}$ of previously established economic weights;

$\mathrm{g}$ : $\mathrm{n} \times \mathrm{p}$ dimension matrix of unknown genetic values of the $n$ characters considered.

The vector $\mathrm{b}=\mathrm{P}-1 \mathrm{Ga}$, where $\mathrm{P}^{-1}$ is the inverse of the matrix, dimension $\mathrm{n} x \mathrm{n}$, of phenotypic variances and covariance between the characters. $G$ is the matrix, dimension $n \times n$, of genetic variances and covariance between characters.

The expected gain for character $j$ was expressed by:

$$
\Delta g_{i(i)}=D S_{i(i)} h^{2} j
$$

On what:

$\Delta g \mathrm{j}(\mathrm{i})=\mathrm{g} \mathrm{j}$ (i): expected gain for character $\mathrm{j}$, with selection based on index I;

DS $j$ (i): selection differential for character $j$, with selection based on index I;

$\mathrm{h}^{2} \mathrm{j}$ : heritability of character $\mathrm{j}$.

In the index of the sum of "ranks" of Mulamba and Mock (1978) the orders of each genotype were added, resulting in the selection index, as described below: 
$I=r_{1}+r_{2}+\cdots+r_{n}$

On what:

I: value of the index for a given individual or family;

rj: classification (or "rank") of an individual in relation to the $\mathrm{j}$-th character;

$\mathrm{n}$ : number of characters considered in the index. Weights were given by:

$I=p_{1} r_{1}+p_{2} r_{2}+\cdots+p_{n 2} r_{n}$

On what:

pj: economic weight attributed to the $j$-th character.

For the Willians base index (1962), the

following index was used as a selection criterion:

$I=a_{1} y_{1}+a_{2} y_{2}+\cdots+a_{n} y_{n}=\sum_{i=1}^{n}$ aiyi $=y^{\prime} a$

On what:

$\mathrm{y}$ : are the averages;

a: are the economic weights of the characters studied.
The selection criterion used was to reduce the production cycle character and increase the other characters for the direct selection and Mulamba and Mock (1978) indexes. In the Smith (1936) and Hazel (1943) and Willians' (1962) base indexes, an increase was considered for all characteristics. The economic weight adopted was the coefficient of genetic variation for each variable, as recommended by Cruz et al. (2012). The data were analyzed using the Genes Program (Cruz, 2013).

\section{RESULTS AND DISCUSSION}

It is observed the existence of genetic variability for the characters: Productivity, Number of fruits, leaf area index, precocity, NDVI and NDRE and the SPAD variable (Table 2). Only leaf temperature was not significant Probably evaluations of leaf temperature in different vegetative phases could lead to significant differences for this variable. Therefore, it evidences the possibility of selecting agronomically superior accessions for the analyzed characteristics (CRUZ et al., 2012).

Table 2. Average squares, coefficients of variance and genetic parameters of variables of the 65 pumpkin genotypes.

\begin{tabular}{ccccccc}
\hline Characters $^{1}$ & $\mathrm{QMG}^{2}$ & $\mathrm{~h}^{2}(\%)$ & $\mathrm{CVg}(\%)$ & $\mathrm{CVe}(\%)$ & $\mathrm{CVg} / \mathrm{CVe}$ & $\mathrm{AS} \%$ \\
\hline $\mathrm{Y}$ & $0,5738^{* *}$ & 47,76 & 30,94 & 56,26 & 0,55 & 68,32 \\
$\mathrm{NF}$ & $3,0138^{* *}$ & 47,96 & 25,62 & 46,58 & 0,55 & 68,83 \\
$\mathrm{~T}$ & $7,3469^{\mathrm{ns}}$ & 8,83 & 1,84 & 10,22 & 0,18 & 68,97 \\
$\mathrm{LAI}$ & $0,0231^{* *}$ & 45,81 & 18,70 & 35,28 & 0,53 & 68,55 \\
$\mathrm{P}$ & $57,5878^{* *}$ & 59,65 & 9,82 & 14,03 & 0,70 & 77,23 \\
SPAD & $498,9583^{*}$ & 36,92 & 11,07 & 25,16 & 0,44 & 60,76 \\
NDVI & $0,0163^{* *}$ & 46,78 & 17,51 & 32,43 & 0,54 & 71,44 \\
NDRE & $0,0023^{* *}$ & 54,65 & 26,32 & 41,78 & 0,63 & 73,53
\end{tabular}

${ }^{1}$ Y: yield; NF: number of fruits; T: leaf temperature; LAI: leaf area index; P: precocity; SPAD: SPAD index; NDVI: NDVI index; NDRE: index NDRE index. ${ }^{2} \mathrm{QMG}$ : average square of the genotypes; $\mathrm{H}^{2}$ : coefficient of genotypic determination; CV: coefficient of general variation; CVg: coefficient of genetic variation; CVe: coefficient of experimental variation; ** and $*$ significant at the level of $1 \%$ and $5 \%$ probability, respectively, by the $\mathrm{F}$ test; ns: not significant.

The coefficient of genetic variation $(\mathrm{CVg} \%)$, adopted as economic weight, the variables in decreasing order were: Productivity, number of fruits, leaf area index, NDRE, NDVI, SPAD, Precocity and leaf temperature.

The coefficient of variation (CV\%) showed values of $56.05 \%$ for productivity, $46.23 \%$ for number of fruits, $35.22 \%$ for leaf area index, $32.25 \%$ for NDVI and $41.52 \%$ for NDRE. A coefficient of variation above $30 \%$ is considered high, indicating a high dispersion of experimental data, which may have been caused by the genetic variability between the materials studied. A high coefficient of variation can also be explained by the fact that they are quantitative characters controlled by many genes and highly affected by the environment (TEIXEIRA, 2017). 
However, to analyze the quality of experiments in a genetic improvement program, where there is possibly high variability, the accuracy is a more appropriate parameter, as it includes the coefficient of experimental variation, the repetitions and the coefficient of genetic variation, with the best values being close to $100 \%$. They are classified as very high above $90 \%$, high between $70 \%$ and $90 \%$, moderate between $50 \%$ and $70 \%$ and low to less than 50\% (RESENDE; DUARTE, 2007). The variables showed moderate to high, which suggests that they are influenced by the environment.

The knowledge of the coefficient of genotypic determination $\left(\mathrm{h}^{2}\right)$ allows the establishment of an estimate of the genetic gain to be obtained, as it reflects the proportion of the phenotypic variation that is inheritable in nature and defines the best strategy to be used in the genetic improvement program (BALDISSERA et al., 2014).
They are considered high when higher than 0.7 (RAMALHO et al., 2012), although Borges et al., (2019) reports that heritability values above $30 \%$ indicate a strong possibility of success in a pumpkin selection program.

Silva (2010) evaluated the phenotypic and genotypic behavior for the development of a new pumpkin cultivar (C. moschata) with a cordiform shape and thick pulp. Values of the $\mathrm{CVg} / \mathrm{CVe}$ ratio higher than 1 most characters were found, corroborating with de Silva (2016) and Blank et al. (2013).

In the phenotypic and genotypic correlations, it is to know the association between the characters. It is possible to observe that the direct selection of multiple characters may reduce the improved population mean for some characteristics (Table 3).

Table 3. Phenotypic and genotypic correlations between characters evaluated in 65 pumpkin genotypes $(C$.

\begin{tabular}{|c|c|c|c|c|c|c|c|c|c|}
\hline & \multirow[t]{2}{*}{ Correlation } & \multicolumn{8}{|c|}{ Caracthers } \\
\hline & & $\mathbf{Y}$ & NF & $\mathbf{T}$ & LAI & $\mathbf{P}$ & SPAD & NDVI & NDRE \\
\hline \multirow{2}{*}{${ }^{1} \mathbf{Y}$} & $\mathrm{RFE}^{\S}$ & 1,00 & $0,82 * *$ & $-0,26^{*}$ & $0,44^{* *}$ & $-0,43 * *$ & 0,1 & 0,23 & $0,30 *$ \\
\hline & $\mathrm{RGE}^{\S}$ & 1,00 & $0,78^{* *}$ & $-0,63$ & 0,37 & $-0,59 * *$ & 0,25 & 0,25 & $0,33 *$ \\
\hline \multirow{2}{*}{ NF } & RFE & & 1,00 & $-0,33 *$ & $0,26 *$ & $-0,43 * *$ & 0,13 & 0,15 & 0,23 \\
\hline & RGE & & 1,00 & $-0,89$ & $0,00 *$ & $-0,54$ & 0,29 & 0,19 & 0,26 \\
\hline \multirow{2}{*}{$\mathbf{T}$} & RFE & & & 1,00 & $-0,27 *$ & 0,00 & $-0,06$ & $-0,18$ & $-0,15$ \\
\hline & RGE & & & 1,00 & $-0,77$ & $-0,17$ & $-1,02 * *$ & $-0,21$ & $-0,21$ \\
\hline \multirow{2}{*}{ LAI } & RFE & & & & 1,00 & $-0,16$ & 0,17 & $0,46^{* *}$ & $0,42 * *$ \\
\hline & RGE & & & & 1,00 & $-0,05$ & 0,42 & 0,48 & 0,4 \\
\hline \multirow{2}{*}{$\mathbf{P}$} & RFE & & & & & 1,00 & $-0,04$ & 0,06 & $-0,04$ \\
\hline & RGE & & & & & 1,00 & 0,00 & 0,17 & $-0,03$ \\
\hline \multirow{2}{*}{ SPAD } & RFE & & & & & & 1,00 & $0,38 * *$ & $0,38 * *$ \\
\hline & RGE & & & & & & 1,00 & $1,09 * *$ & $1,11 * *$ \\
\hline \multirow{2}{*}{ NDVI } & RFE & & & & & & & 1,00 & $0,80 * *$ \\
\hline & RGE & & & & & & & 1,00 & $0,86^{* *}$ \\
\hline \multirow{2}{*}{ NDRE } & RFE & & & & & & & & 1,00 \\
\hline & RGE & & & & & & & & 1,00 \\
\hline
\end{tabular}

${ }^{1}$ Y: yield; NF: number of fruits; T: leaf temperature; LAI: leaf area index; P: precocity; SPAD: SPAD index; NDVI: NDVI index; NDRE: index NDRE index.

***: Significant at 1 and $5 \%$ probability by $\mathrm{T}$ test.

${ }^{\S}$ Estimates of the phenotypic (RFE) and genotypic (RGE) correlation coefficients, between the characters evalueted.

The averages of leaf temperature and precocity, in general, have a negative correlation with the other characteristics, that is, when selecting multiple characteristics. Leaf temperature and precocity tend to decrease, which can be favorable, since optimal leaf temperature benefits metabolic activities, as well as low precocity values are desirable, as long as good productivity is maintained, a direct reflection on the selection gain (Table 3).

The selection gains for the nine characters evaluated can be seen in Table 4. 
Table 4. Estimates of selection gains $(\mathrm{SG} \%)$ obtained for nine characters evaluated, by direct and indirect selection, for 65 pumpkin genotypes.

\begin{tabular}{cccccccccc} 
Characters $^{1}$ & \multicolumn{7}{c}{ SG\% } \\
\cline { 2 - 10 } & Y & NF & T & IAF & P & SPAD & NDVI & NDRE & Total \\
\cline { 2 - 9 } Y & $\mathbf{3 5 , 9 2}$ & 25,75 & $-0,25$ & 9,52 & $-3,44$ & 2,74 & 1,57 & 3,26 & 75,07 \\
NF & 31,00 & $\mathbf{2 8 , 9 3}$ & $-0,02$ & 3,23 & $-4,65$ & $-1,62$ & $-1,90$ & $-2,60$ & 52,37 \\
T & $-15,12$ & $-12,6$ & $\mathbf{0 , 9 6}$ & $-6,72$ & $-2,46$ & $-0,37$ & $-2,88$ & $-5,65$ & $-58,32$ \\
IAF & 13,44 & 5,05 & $-0,21$ & $\mathbf{2 2 , 7 2}$ & $-2,11$ & $-0,02$ & 5,80 & 9,13 & 53,08 \\
P & 15,5 & 16,59 & $-0,03$ & 0,25 & $\mathbf{0 , 2 5}$ & $-9,27$ & $-0,76$ & 0,48 & 24,15 \\
SPAD & 6,65 & 5,08 & $-0,03$ & 4,23 & $-3,55$ & $\mathbf{9 , 9 4}$ & 6,88 & 11,94 & 41,14 \\
NDVI & 12,56 & 3,38 & $-0,03$ & 11,05 & $-1,99$ & 4,86 & $\mathbf{1 8 , 5 3}$ & 31,64 & 80,00 \\
NDRE & 13,65 & 9,57 & $-0,05$ & 9,81 & $-2,63$ & 5,71 & 17,29 & $\mathbf{3 3 , 0 4}$ & $\mathbf{8 6 , 3 9}$ \\
\hline
\end{tabular}

${ }^{1}$ Y: yield; NF: number of fruits; T: leaf temperature; LAI: leaf area index; P: precocity; SPAD: SPAD index; NDVI: NDVI index; NDRE: index NDRE index.

The greatest gains obtained with direct and indirect selection were for the character's productivity $(35.92 \%)$, NDRE $(33.04 \%)$, number of fruits $(28.93 \%)$ and leaf area index $(22.72 \%)$. The selection for the character's precocity and leaf temperature $(0.25 \%$ and $0.96 \%)$, respectively, obtained the lowest values, which is consistent with the low $\mathrm{CVg}(9.82 \%$ and $1.84 \%$, respectively).
Higher estimates of the coefficients of genotypic variation indicate the greater possibility of genetic disorders with selection (FREITAS et al., 2009).

The Mulamba and Mock index (1978) showed the highest selection gains for productivity $(25.11 \%)$, number of fruits $(17.00 \%)$ and leaf area index $(14.18 \%)$, as well as the highest value of total selection gain (Table 5).

Table 5. Estimates of selection gains (SG\%) obtained for nine variables, among 65 pumpkin genotypes, obtained by the classic index proposed by Smith and Hazel (SH), Mulamba and Mock (MM) ranks sum index and Willians' base index (W).

\begin{tabular}{cccccccccc}
\hline \multirow{2}{*}{ Indexes } & \multicolumn{7}{c}{ SG\% } & \multirow{2}{*}{ Total } \\
& $\mathrm{Y}^{1}$ & $\mathrm{NF}$ & $\mathrm{T}$ & $\mathrm{IAF}$ & $\mathrm{P}$ & $\mathrm{SPAD}$ & NDVI & NDRE & \\
\cline { 2 - 7 } $\mathrm{W}$ & 6,14 & 7,93 & 0,11 & 2,79 & 3,20 & 9,08 & 3,36 & 6,08 & 38,69 \\
$\mathrm{SH}$ & 6,07 & 5,15 & $-0,09$ & 6,49 & 0,60 & 7,97 & 15,12 & 29,29 & 70,60 \\
$\mathrm{MM}$ & 25,11 & 17,00 & $-0,26$ & 14,18 & $-4,30$ & 5,48 & 15,44 & 25,31 & $\mathbf{9 7 , 9 6}$ \\
\hline
\end{tabular}

${ }^{1}$ Y: yield; NF: number of fruits; T: leaf temperature; LAI: leaf area index; P: precocity; SPAD: SPAD index; NDVI: NDVI index; NDRE: index NDRE index

For yield there is the possibility of gains between 6.07 to $25 \%$. Considering the average production of pumpkins around 417,839 tons (IBGE, 2017), increases of around 6\% would represent a great increase in national production.

In a study by Ferreira et al. (2016) the greatest gains expected with the selection (SG\%) were found for the characteristics of fruit mass ($96.80 \%$ ) and location of the node of the first male flower $(-64.32 \%)$. As for the number of branches and number of branches of the tendril, the lowest estimates of expected gain with the selection were observed (3.48 and 7.60\%, respectively), which can be justified by the lower genetic variability for these characteristics.

Strains 8, 31, 42, 68 stood out as superior genotypes concomitantly for the selection indexes of Willians (1962) and Mulamba and Mock (1978) (Table 5). There is no genotype selected by the Smith (1936) and Hazel (1943) index that was selected by the other indexes. The Mulamba and Mock (1978) index showed the highest total selection gain value, providing a balanced distribution of selection gains, with genotypes being 
selected: Abobrinha 11 \# 1 (8), Abobrinha 62 \# 1 (31), Abobrinha 69 \# 1 (34), Abobrinha 77 \# 1 (38), Abobrinha 85 \# 1 (42), UFU-E (64), UFU-B (65),
UFU-C (66), PX13067051 (67) and UFU-G (68).68 as those with greater agronomic potential for use in selection (Table 6).

Table 6. Indication of the ten superior pumpkin genotypes, selected based on productivity, using the classic index proposed by Smith (1936) and Hazel (1943), Mulamba and Mock's rank (1978) sum index and base index Willians.

\begin{tabular}{ccc}
\hline & Selection indexes & \\
\hline Willians (1962) & Smith (1936) and Hazel (1943) & $\begin{array}{c}\text { Mulamba and Mock } \\
(1978)\end{array}$ \\
\hline 42 & 9 & 65 \\
20 & 50 & 66 \\
68 & 33 & 68 \\
8 & 13 & 64 \\
28 & 36 & 8 \\
69 & 12 & 42 \\
29 & 45 & 34 \\
66 & 11 & 67 \\
31 & 39 & 31 \\
44 & 27 & 38 \\
\hline
\end{tabular}

For the estimation of selection gains, only ten individuals were selected using the direct and indirect selection methodologies (CRUZ et al., 2012); classic index, proposed by Smith (1936) and Hazel (1943); Mulamba and Mock ranks index (1978) and Willians base index (1962). However, a restricted selection, less than $20 \%$ of the best individuals, can cause narrowing of the genetic base, as it decreases genetic variability.

Faustino (2017) evaluated 11 pumpkins $(C$. moschata) genotypes for qualitative and quantitative morpho-agronomic and chemical-quality characteristics of the pulp, including carotenoid content. It used the multi-effect indexes and the index proposed by Mulamba and Mock (1978), with a selection intensity of $10 \%$. The ranking of individuals, both of variables with greater commercial relevance and through a selection index considering all the characters evaluated, selected two potentially interesting genotypes for the next selection cycle in pumpkin with a piriform shape.

Borges et al. (2019) evaluating ten progenies for 17 morpho-economic and chemical quality characteristics of the pulp, used a selection intensity of $10 \%$, also through the selection index of
Mulamba and Mock (1978). Bezerra Neto et al. (2006) evaluated five morpho-agronomic traits in seven strains of pumpkin (C. moschata), submitted to the estimation of genetic parameters and to the analysis of simple and canonical correlations. In this work, genotypes of commercial interest, containing smaller fruit and thick pulp, could be obtained using the selection index technique.

\section{CONCLUSIONS}

The Mulamba and Mock (1978) sum of ranks index was considered in this work as the most adequate criterion. Using this index was selected the lines: Abobrinha 11 \# 1 (8), Abobrinha 62 \# 1 (31), Abobrinha 69 \# 1 (34), Abobrinha 77 \# 1 (38), Abobrinha 85 \# 1 (42), UFU-E (64), UFU-B (65), UFU-C (66), PX13067051 (67) and UFU-G (68).

\section{ACKNOWLEGDMENT}

We thank UFU, PROPP, CAPES, FAPEMIG, CNPq and the Company JULIAGRO®.

RESUMO: No melhoramento de abóboras, a seleção baseada em um ou alguns caracteres de interesse tende a ser pouco eficiente, levando a um produto superior apenas em comparação com os poucos caracteres selecionados. Para maximizar a seleção simultânea de múltiplas características de interesse, os índices de seleção são utilizados visando obter um valor numérico resultante da combinação dos caracteres sobre os quais será praticada. O objetivo deste trabalho foi determinar parâmetros genéticos e os índices de seleção mais adequados em linhagens de abóbora (C. pepo). As análises estatísticas foram realizadas com base em 65 genótipos pertencentes ao banco de germoplasma de hortaliças da Universidade Federal de Uberlândia. As 
variáveis analisadas foram: índice de área foliar, precocidade, índice SPAD, produtividade. planta $^{-1}$, número de frutos. Planta ${ }^{-1}$, temperatura foliar, índice NDVI e índice NDRE. Foram utilizados os índices: Smith (1936) e Hazel (1943), a soma de "Ranks" de Mulamba e Mock (1978) e Willians (1962). As metodologias de seleção selecionaram dez indivíduos (15\% dos genótipos). Os valores encontrados para $\mathrm{h}^{2}(\%)$ variaram de 36,92\% (SPAD) a 59,65\% (ciclo). Os valores obtidos no quociente CVg / CVe foram inferiores a 1, variando de 0,18 para a temperatura foliar a 0,70 para o ciclo, com as demais variáveis próximas de 0,5 . O coeficiente de variação genética $\mathrm{CVg}(\%)$ também foi baixo, variando de 1,84\% para temperatura foliar a 30,94\% para produtividade. Os maiores ganhos obtidos com a seleção direta e indireta foram para os caracteres produtividade $(35,92 \%)$, NDRE $(33,04 \%)$, número de frutos $(28,93 \%)$ e índice de área foliar $(22,72 \%)$. O índice de Mulamba e Mock (1978) apresentou o maior valor de ganho de seleção total, proporcionando uma distribuição balanceada de ganhos de seleção, escolhendo os genótipos: 8, 31, 34, 38, 42, 64, 65, 66, 67 e 68 .

PALAVRAS-CHAVE: Abobrinha Italiana. Cruzamentos. Ganhos de seleção.

\section{REFERENCES}

BALDISSERA, J. N. C.; VALENTINI, G.; COAN, M. M. D.; GUIDOLIN, A. F.; COIMBRA, J. L. M. Genetics factors related with the inheritance in autogamous plant populations. Journal of Agroveterinary Sciences, Lages, v. 13, n. 2, p. 181-189, 2014.

BEZERRA NETO, F. V.; LEAL, N. R.; COSTA, F. R.; GONÇALVES, G. M.; AMARAL JÚNIOR, A. T.; VASCONCELLOS, H.O.; MIGUEL MELLO, M. Análise biométrica de linhagens de abóbora. Horticultura Brasileira, Brasília, v. 24, p. 378-380, 2006. http://dx.doi.org/10.1590/S0102-05362006000300022

BLANK, A. F.; SILVA, T. B.; MATOS, M. L.; CARVALHO FILHO, J. L. S.; SILVA-MANN, R. Parâmetros genotípicos, fenotípicos e ambientais para caracteres morfológicos e agronômicos em abóbora. Horticultura Brasileira, Brasília, v. 31, p. 106-111, 2013. http://dx.doi.org/10.1590/S0102-05362013000100017

BORGES, R. M. E. B.; LIMA, M. A. C.; LIMA NETO, I. S.; MELO, N. F. Prediction of genetic and selection parameters in pumpkin (Cucurbita moschata Duch.) progenies for morphoagronomic characteristics and pulp quality, Australian Journal of Crop Science [online], v.13, n.02, p. 199-207, 2019.

http://dx.doi.org/10.21475/ajcs.19.13.02.p1192

CRUZ, C. D. Simultaneous selection in progenies of yellow passion fruit using selection indices. Revista Ceres, Viçosa, v. 59, n. 1, p. 95-101, Jan./Feb. 2012. http://dx.doi.org/10.1590/S0034-737X2012000100014.

CRUZ, C. D. GENES: a software package for analysis in experimental statistics and quantitative genetics. Acta Scientiarum- Agronomy, Maringá, v. 35, p. 271-276, July/Sept. 2013.

https://doi.org/10.4025/actasciagron.v35i3.21251

FAUSTINO, R. M. E. B. Predição de parâmetros genéticos e incremento da qualidade em frutos de progênies de aboboreira (Cucurbita moschata duch.). Thesis (Doctoral in genetic vegetable resources) Feira de Santana State University, Feira de Santana, 2017.

FERREIRA, M. G.; SAlVADOR, F. V.; LIMA, M. N. R.; AZEVEDO, A. M.; LIMA NETO, I. S.; SOBREIRA, F. M.; SILVA, D. J. H. Parâmetros genéticos, dissimilaridade e desempenho per se em acessos de abóbora. Horticultura Brasileira, Brasília, v. 34, p. 537-546, 2016. http://dx.doi.org/10.1590/S0102$\underline{053620160413}$

FORMISANO, G.; ROIG C.; ESTERAS, C.; ERCOLANO, M.R.; NUEZ, F.; MONFORTE, A.J.; PICÓ, M.B. Genetic diversity of Spanish Cucurbita pepo landraces: an unexploited resource for summer squash breeding. Genetic Resources and Crop Evolution [online], 59, p. 1169-1184, 2012.

https://doi.org/10.1007/s10722-011-9753-y 
FREITAS, R. G.; VASCONCELOS, E. S.; CRUZ, C. D.; ROSADO, A. M.; ROCHA, R. B.; TAKAMI, L. K. Predição de ganhos genéticos em progênies de polinização aberta de Eucalyptus urograndis cultivadas em diferentes ambientes e submetidas a diferentes procedimentos de seleção. Revista Árvore [online], v. 33, p. 255-263, 2009. http://dx.doi.org/10.1590/S0100-67622009000200007

HAZEL, L.N. The genetic basis for constructing selection indexes. Genetics, Princeton, v. 28: 476-490, 1943.

IBGE, Censo agro 2017. Avaliable from:

$<\underline{\text { https://censos.ibge.gov.br/agro/2017/templates/censo agro/resultadosagro/agricultura.html?localidade }=0 \& \text { tem }}$ $\underline{\mathrm{a}=76409>\text { Accessed in march } 242020 .}$

KÖPPEN, W.; GEIGER, R. Handbuch der Klimatologie, Berlin: G. Borntraeger, 1939, 44p.

LEITE, W. S.; PAVAN, B. E.; MATOS FILHO, C. H. A.; DE ALCANTARA NETO, F.; DE OLIVEIRA, C. B.; FEITOSA, F. S. Genetic parameters estimation, correlations and selection indexes for six agronomic traits in soybean lines F8. Comunicata Scientiae, Bom Jesus, v. 7, n. 3, p. 302-310, 2016.

https://doi.org/10.14295/cs.v7i3.1176

MATSUO, E.; CRUZ, C. D.; SEDYAMA, T. Aplicações de Técnicas Biométricas no Melhoramento Genético da Soja. $1^{\text {st }}$ ed., Editora UFV, Viçosa, 2020, 256p.

MULAMBA, N. N.; MOCK, J. J. Improvement of yield potential of the Eto Blanco maize (Zea may L.) population by breeding for plant traits. Egyptian Journal of Genetics and Cytology, Cairo, v.7, p. 40-51, 1978.

NOGUEIRA, A. P. O.; SEDIYAMA, T.; SOUSA, L. B.; HAMAWAKI, O. T.; CRUZ, C. D.; PEREIRA, D. G.; MATSUO, E. Análise de trilha e correlações entre caracteres em soja cultivada em duas épocas de semeadura. Bioscience Journal, Uberlândia, v. 28, n. 6, p. 877-888, 2012.

RAMALHO, M. A. P.; ABREU, A. F. B.; SANTOS, J. B. dos; NUNES, J. A. R. Aplicações da genética quantitativa no melhoramento de plantas autógamas. Lavras: Editora UFLA, 2012, 522p.

RESENDE, M. D. V.; DUARTE, J. B. Precisão e controle de qualidade em experimentos de avaliação de cultivares. Pesquisa Agropecuária Tropical, Goiânia, v. 37, p. 182-194, 2007.

REZENDE, J. C.; BOTELHO, C. E.; OLIVEIRA, A. C. B.; SILVA, F. L.; CARVALHO, G. R.; PEREIRA, A. A. Genetic progress in coffee progenies by different selection criteria. Coffee Science, Lavras, v. 9 p. 347-353, 2014. http://dx.doi.org/10.25186/cs.v9i3.643

RIBEIRO, A. C.; GUIMARÃES, P. T. G.; ALVAREZ, V. V. H. (Ed.). Recomendações para o uso de corretivos e fertilizantes em minas gerais: $5^{\text {a }}$ aproximação. Viçosa, MG: Comissão de Fertilidade do Solo do Estado de Minas Gerais, 1999, 359p.

ROSADO, L. D. S.; SANTOS, C. E. M. D.; BRUCKNER, C. H.; NUNES, E. S.; CRUZ, C. D. Simultaneous selection in progenies of yellow passion fruit using selection indices. Revista Ceres, Viçosa, v. 59, n. 1, p. 95101, 2012. http://dx.doi.org/10.1590/S0034-737X2012000100014.

SILVA, P. C. Variabilidade genética de abóboras na região metropolitana de Manaus, Estado do Amazonas. Dissertation (Agriculture in the Humid Tropics) - National Institute for Research in the Amazon, Manaus, 2016.

SILVA, T. B. Seleção, comportamento fenotípico e genotípico e desenvolvimento de uma nova cultivar de abóbora (Cucurbita moschata Dusch). Dissertation (Post-Graduation in Agroecosystems)- Federal University of Sergipe, Aracuju, 2010. 
Genetic parameters...

BELOTI, I. F. et al.

SMITH, H. F. A Discriminant Function for Plant Selection. Annals of Eugenics, London, v. 7, p. 240-250, 1936. https://doi.org/10.1111/j.1469-1809.1936.tb02143.x

TEIXEIRA, F. G. Herança da precocidade e de caracteres agronômicos em soja e seleção de linhagens com base em índices de seleção. Dissertation (Graduate Program in Agronomy)- Federal University of Uberlândia, 2017.

VASCONCELOS, E. S.; FERREIRA, R. P.; CRUZ, C. D.; MOREIRA, A.; RASSINI, J. B.; FREITAS, A. R. Estimativas de ganho genético por diferentes critérios de seleção em genótipos de alfafa. Revista Ceres, Viçosa, v. 57 p. 205-210, 2010. http://dx.doi.org/10.1590/S0034-737X2010000200011

WILLIAMS, J.S. The evaluation of a selection index. Biometrics, Madison, v.18, p.375-393, 1962. 